\title{
Predictors of Deviant Behavior Justification Among Muslims: Sociodemographic Factors, Subjective Well-Being, and Perceived Religiousness
}

\author{
Nur Amali Aminnuddin ${ }^{1 *}$, (D) Harris Shah Abd. Hamid ${ }^{2}$ \\ ${ }^{1}$ Universiti Brunei Darussalam, Brunei Darussalam \\ 2University of Malaya, Malaysia \\ @aminnuddin.na@gmail.com*
}

Article Information:

Received September 18, 2021

Revised October 19, 2021

Accepted October 20, 2021

Keywords: deviant behavior; individual differences; islam; muslims; religiousness; wellbeing

\begin{abstract}
Current evidence supports how deviant behavior can be predicted by sociodemographic factors, subjective well-being, and perceived religiousness. However, there is limited research when it concerns specificity such as Muslims justifying deviant behavior, and their subjective well-being and perceived religiousness within a single study. Most studies used Christian population or using a non-denominational approach. Therefore, in this study, data from World Value Survey Wave 6 was used to examine the Muslim population $(N=20,559)$ and deviant behavior justification. Sociodemographic factors, subjective well-being (life satisfaction, happiness, and state of health), and perceived religiousness (prayer frequency and importance of God in life) were hypothesized as predictors. Results revealed that these hypotheses are supported. However, many of these predictors are weak, having minimal effect. This is with the exception of having the worldview of God being important in one's life, being both a strong and statistically significant predictor of deviant behavior justification. The more a person views God being important in life, the more it predicts a decrease in deviant behavior justification. This research provides a novel finding on the belief-behavior nexus, specifically concerning Muslims justifying deviant behavior when two forms of perceived religiousness-ritualistic and worldview-are being compared.
\end{abstract}

\section{INTRODUCTION}

Deviant behavior is subjective by nature (Goode, 2019). It is defined and constructed by society, based on the behavior being viewed negatively or in a pejorative manner. Due to this, deviant behavior tends to be treated as a societal problem. The deviancy degree of a deviant behavior and its impact can be wide-ranging. It comes in various forms (McCaghy et al., 2016). It can be an action done against a person, a group of people, or properties. It can be observed in organizations or in the cyberspace. Making a white lie can be viewed as a minor deviant behavior as its impact is almost negligible. At the opposite end, it can be extreme to the point that it affects society, for example, scamming others or committing frauds.

There have been studies on various deviant behaviors, including juvenile delinquency (Hong Chui et al., 2020), discrimination of certain groups (Aminnuddin, 2019a, 2020a, 2020b), substance use (Baker et al., 2020), and self-injurious behavior (Bakken, 2021). Researchers have also examined deviant behaviors based on specific population such as based

How to cite:

E-ISSN:

Published by:
Aminnuddin, N., \& Abd. Hamid, H. (2021). Predictors of Deviant Behavior Justification among Muslims: Sociodemographic Factors, Subjective Well-Being, and Perceived Religiousness. Islamic Guidance and Counseling Journal, 4(2). https://doi.org/10.25217/igcj.v4i2.1814 2614-1566

Institut Agama Islam Ma'arif NU (IAIMNU) Metro Lampung 
on age group (Simons et al., 2009), religious denomination (Nie, 2020), and race (Baker et al., 2020).

With the growing number of Muslims, it is necessary to understand them and their way of life (Rice, 1999). This is crucial because, for Muslims, Islam influences every aspect of their life due to the values the religion brings. It provides a specific worldview, i.e., an Islamic worldview, and frameworks guided by the objectives of the Shari'ah, which theoretically are applicable to various contexts, such as in the context of the family institution (Isa, 2021). The impact it has toward Muslims includes on consumer attitude (Salam et al., 2019) and behavior (Muhamad \& Mizerski, 2010), and activism (Muhamad et al., 2019). Religiousness is also linked to having meaning in life (Muarifah et al., 2020). Furthermore, religion may influence ethical behavior in the workplace (Aminnuddin, 2019b, 2019c, 2020c). It is also associated with organizational commitment (Husin \& Kernain, 2020). Religion plays the role of a moral compass or acts as a control mechanism (McCullough \& Willoughby, 2009). When religion is integrated as part of an intervention, it also helps improve the desirable outcome (Kadafi et al., 2021).

Even with existing studies, there is still limited scholarship in current literature concerning psychology of Islam and Muslims (Abu-Raiya, 2013). There is much to be done, having numerous potential research areas to be explored. At this point, studies on Muslims are undeniably increasing. One such area that warrants further exploration is concerning individual differences, particularly on deviant behavior.

Deviant behavior can have important consequences at individual and societal levels. It has moral, philosophical, financial, and religious implications. Behaving unethically or in a deviant manner may also be justified as a means to an end. Within a society, social class shapes a person's worldview (Piff et al., 2016). The more privileged the person is, the more they tend to focus on self-interest, doing things that will protect or advance their status (Piff et al., 2012). However, rather than social class exclusively predicts deviant behavior, a better predictor is whether or not the act can benefit them (Dubois et al., 2015). This can be explained through the theory of abundance effect: people are more likely to cheat in a situation where they will gain more financially (Gino \& Pierce, 2009). The theory proposed that the motivation driving deviant behavior is envy. While others had observed that it can be predicted by a favorable attitude toward greed as a positive trait (Piff et al., 2012).

It is far more complex than just simply being part of the lower class or the upper class (Trautmann et al., 2013). Two factors relevant to this paper have been identified: (1) wellbeing and (2) religiousness. Using happiness, which is part of well-being, as an example, it has been linked to being less likely to justify deviant behavior (James Jr., 2011). Similarly, a person's deviant tendency or behavior can be inhibited by one's religion or religiousness (Smith et al., 2005). The causes and consequences of deviant behavior have been widely discussed (Appelbaum et al., 2007), especially in the context of the workplace (Robinson et al., 2014). Deviant behavior affects well-being negatively for both the perpetrators and the victims, even for those who merely witness it (Giacalone \& Promislo, 2010). Actors of deviant behavior tend to have life issues such as trust in relationship, holding on to a job, and depressive symptoms. This is more prevalent among those who had been institutionalized relative to those who were not (Lanctôt et al., 2007).

Having superiors with deviant profile in the workplace also contribute to poor wellbeing and counterproductive work behavior among individuals (Boddy, 2014). When an employee experiences job insecurity, it negatively affects their satisfaction, which also leads to engaging in deviant behavior (Reisel et al., 2010). In another example, when they return to work after a vacation, their stress level will decrease, resulting to a decline in absenteeism (Westman \& Etzion, 2001), suggesting that better well-being is associated with lower odds of deviant behavior in the workplace. Similarly, satisfaction influences ethical behavior 
positively (Fu, 2014). The more satisfied the person is, the more likely the individual will externalize ethical behavior. This can also be observed the other way around. When the individual is less satisfied, they tend to act unethically (Wu et al., 2019). At this point, there is reasonable evidence that well-being is linked to ethical/unethical behavior.

Other than well-being, religion or religiousness has a strong deviance-inhibiting effect (Smith et al., 2005). Religious individuals have shown higher level of self-control toward substance use (Desmond et al., 2013). They also exhibited more conservative attitude on sexual behavior (Simons et al., 2009). Similar effect has been found on adolescent porn viewing (Nie, 2020) and moral disengagement that can lead to other dishonest acts (Rifani et al., 2021). However, these consequences might only exists within the context of organized religions, and not folk religions (Wang \& Jang, 2017).

It is well-documented on how religion can regulate behavior (McCullough \& Willoughby, 2009) as viewed through the theory of self-regulation (Carver \& Scheier, 1998). Its effect is not only present among adults, but also among adolescents (Pearce et al., 2019), transcending age factor. Furthermore, a person's religiousness can affect ethical judgment (Walker et al., 2012) and ethical acts (Rifani et al., 2021). This is due to aligning religious beliefs with behavior (Keller et al., 2007). However, it also depends on how integral the religion is in the person's life or in the society where the overlap of religion and social norm can be indistinguishable, especially in societies or environment where religion is deeply rooted (Stam et al., 2013). Overall, present literature points toward the notion that religion is a strong predictor of deviant behavior. The more religious a person is, the less likely the person would be engaging in deviant behavior.

\section{Rationale of the Study}

Although the trend of past studies is leaning toward studying deviant behavior itself and the constructs linked to it, this present study instead attempts to examine the justifying of deviant behavior - or deviant behavior justification - by Muslims as a dependent variable. Sociodemographic factors, subjective well-being, and perceived religious will be the independent variables. Currently, there is limited research concerning all three in a single research or that had been done using Muslim population. There is a paucity in existing literature. It is not known to what extent subjective well-being and perceived religiousness can predict deviant behavior justification, especially in the context of the Muslim population. It is only by understanding what are the predictors that scholars in this area can then expand the field, in addition to providing policymakers with empirically supported information. This can help stakeholders to address deviant behavior within the cognitive aspect, i.e., deviant behavior justification. Consequently, this void provides researchers with a potential research growth area that, if addressed, can further assist in understanding the links between the constructs.

\section{Aim and Hypothesis of the Study}

This present study aims to contribute by examining the justifying of deviant behavior by Muslims and its link with sociodemographic factors, subjective well-being, and perceived religiousness as predictors. As the nature of behavior is a sensitive matter and the limitation of the data set used, this present study will only look at its cognitive aspect, i.e., deviant behavior justification, instead of the deviant behavior itself. This study is designed to target Muslims globally to determine the predictive factors. A general and overarching hypothesis is stated here: sociodemographic factors, subjective well-being, and perceived religiousness can predict deviant behavior justification. The study does not present any direction of the prediction-i.e., increase or decrease, predicts high or low likelihood, and such - to prevent preconceived bias. 


\section{METHODS}

\section{Data and Sample Characteristics}

This study used data consisting of Muslims who completed the World Values Survey Wave 6 (Inglehart et al., 2014). Following removal of respondents due to missing data on hypothesized predictors, total of 20,559 Muslims had been identified in the data set. They were from various countries. In alphabetical order, the countries were Algeria, Azerbaijan, Australia, Armenia, Brazil, Belarus, China, Colombia, Cyprus, Estonia, Georgina, Palestine, Germany, Ghana, Hong Kong, India, Iraq, Kazakhstan, Jordan, South Korea, Kyrgyzstan, Lebanon, Libya, Malaysia, Morocco, Netherlands, New Zealand, Nigeria, Pakistan, Peru, Philippines, Romania, Russia, Rwanda, Singapore, Slovenia, South Africa, Spain, Sweden, Thailand, Trinidad and Tobago, Tunisia, Turkey, Ukraine, United States, Uzbekistan, Yemen, and Zimbabwe.

Among the 20,559 Muslims, $48.9 \%$ were male $(n=10,053)$. The mean age was 37.64 years $(S D=14.23$, range $=17-98)$. Participants were generally educated $(21.9 \%$ went to university with or without degree education; $48.2 \%$ went to secondary schools, university preparatory institutions, technical, or vocational institutions; $17.8 \%$ did not complete or had completed primary schools; and $12.1 \%$ had no formal education). In this population, $51.2 \%$ were unemployed $(n=10,535)$, and $35.5 \%$ were not married $(n=7,265)$.

\section{Variables and Coding}

Prior to analysis, all variables were coded accordingly. The dependent variable was deviant behavior justification among Muslims. For this study, items that assessed a respondent's justifying deviant behaviors were averaged to determine the mean: claiming government benefits not entitled to, avoiding fares, stealing properties, cheating on taxes, and accepting bribes. In the data set, the rating ranges between 1 and 10 (Never justifiable to Always justifiable). Prior to the computation, Principal Component Analysis (PCA) was performed on the deviant behavior justification items considering that they are reflective items. The PCA was done with Varimax as the rotation method. Factor loadings are high, with the lowest being .712. The single factor explains $60.4 \%$ of the total variances. Thus, the items can be said to form a unidimensional measure. It was determined that a mean computation is appropriate to be conducted, resulting to an index of deviant behavior justification.

Independent variables were separated into three blocks. In the first block of variables, demographics were assessed, specifically age, sex, education, employment status, and marital status. Except for age and education, all the demographic variables were coded as ordinal variables in binary form: sex $(0=$ Female $; 1=$ Male $)$, employment $(0=$ Unemployed $; 1=$ Employed $)$, and marital status $(0=$ Not married; $1=$ Married $)$. No changes were made on age and level of education. For the latter, a higher number indicate a higher level of education.

In the second block, the predictors tested were indicators of subjective well-being: life satisfaction, happiness, and state of health. The higher the score, the better the respondent's subjective well-being. To reflect this, two variables were reverse coded: happiness $(1=$ Not at all happy; $2=$ Not very happy; $3=$ Rather happy; $4=$ Very happy $)$ and state of health $(1=$ Poor; 2 = Fair; 3 = Good; 4 = Very Good). No changes were done on the variable life satisfaction with the scale ranging between 1 (Completely dissatisfied) and 10 (Completely satisfied).

Finally, the third block consisted of variables that indicated perceived religiousness: prayer frequency and importance of God in life. A higher number reflects a higher level of prayer frequency and a higher level of viewing God being important in life. For prayer frequency, it was reverse coded $(1=$ Never; $2=$ Less often; $3=$ Once a year; $4=$ Only on special holy days; $5=$ Only when attending religious services; $6=$ Several times each week; 7 
Table 1. Demographic Characteristics of Participants

\begin{tabular}{|c|c|c|c|c|}
\hline & $n$ & $M$ & $S D$ & Scale Rating \\
\hline Age & 20,559 & 37.64 & 14.23 & \\
\hline Gender & 20,559 & .49 & .50 & \\
\hline Female & 10,506 & & & \\
\hline Male & 10,053 & & & \\
\hline Level of education & 20,559 & 5.21 & 2.604 & \\
\hline No formal education & 2,485 & & & \\
\hline Incomplete primary school & 1,505 & & & \\
\hline Complete primary school & 2,152 & & & \\
\hline Incomplete secondary school: technical / vocational type & 1,643 & & & \\
\hline Complete secondary school: technical / vocational type & 3,227 & & & \\
\hline Incomplete secondary school: university-preparatory type & 1,882 & & & \\
\hline Complete secondary school: university-preparatory type & 3,163 & & & \\
\hline Some university-level education, without degree & 1,401 & & & \\
\hline University - level education, with degree & 3,101 & & & \\
\hline Employment status & 20,559 & .49 & .50 & \\
\hline Unemployed & 10,535 & & & \\
\hline Employed & 10,024 & & & \\
\hline Marital status & 20,559 & .65 & .48 & \\
\hline Not married & 7,265 & & & \\
\hline Married & 13,294 & & & \\
\hline Life satisfaction & 20,559 & 6.70 & 2.36 & 1 to 10 \\
\hline Happiness & 20,559 & 3.14 & .74 & 1 to 4 \\
\hline State of health & 20,559 & 2.99 & .83 & 1 to 4 \\
\hline Prayer frequency & 20,559 & 6.17 & 2.63 & 1 to 8 \\
\hline Importance of God in life & 20,559 & 9.30 & 1.58 & 1 to 10 \\
\hline
\end{tabular}

= Once a day; 8 = Several times a day). No changes were made to the variable assessing the importance of God in life with the scale ranging from 1 (Not at all important) to 10 (Very important).

Concerning the variables in this research - specifically life satisfaction, happiness, state of health, prayer frequency, and importance of God in life-each of them was treated as a single construct and measured using a single-item indicator. Therefore, no reliability assessment was done on the variables. In terms of validity, each variable was measured as a perceived action or state of the specific construct in a direct and explicit manner. Although the issue of reliability and validity in measuring constructs using a single-item indicator can be discussed from both sides of argument, this would be explained later as part of the limitations in this research. Other studies had done the same when using a single-item measure, including using measures taken from the World Values Survey (e.g., Balish et al., 2016; Beja, 2018; Bruni \& Stanca, 2006; Easterlin et al., 2010; Eichhorn, 2012; Selim, 2008).

\section{Statistical Analysis}

Using SPSS 28, correlation analysis and hierarchical linear regression analysis were conducted. Correlation analysis would show the association value between variables. All variables were then analyzed using hierarchical linear regression analysis. The models provided prediction information through odds ratios of deviant behavior justification based on three blocks of predictors: demographics, subjective well-being, and religiousness.

\section{RESULTS AND DISCUSSION}

Results

Descriptive statistics of the sample population are presented in Table 1. Bivariate correlations between all variables are presented in Table 2. Majority of the paired variables were found to be statistically significant, with several exceptions as noted in the table. 


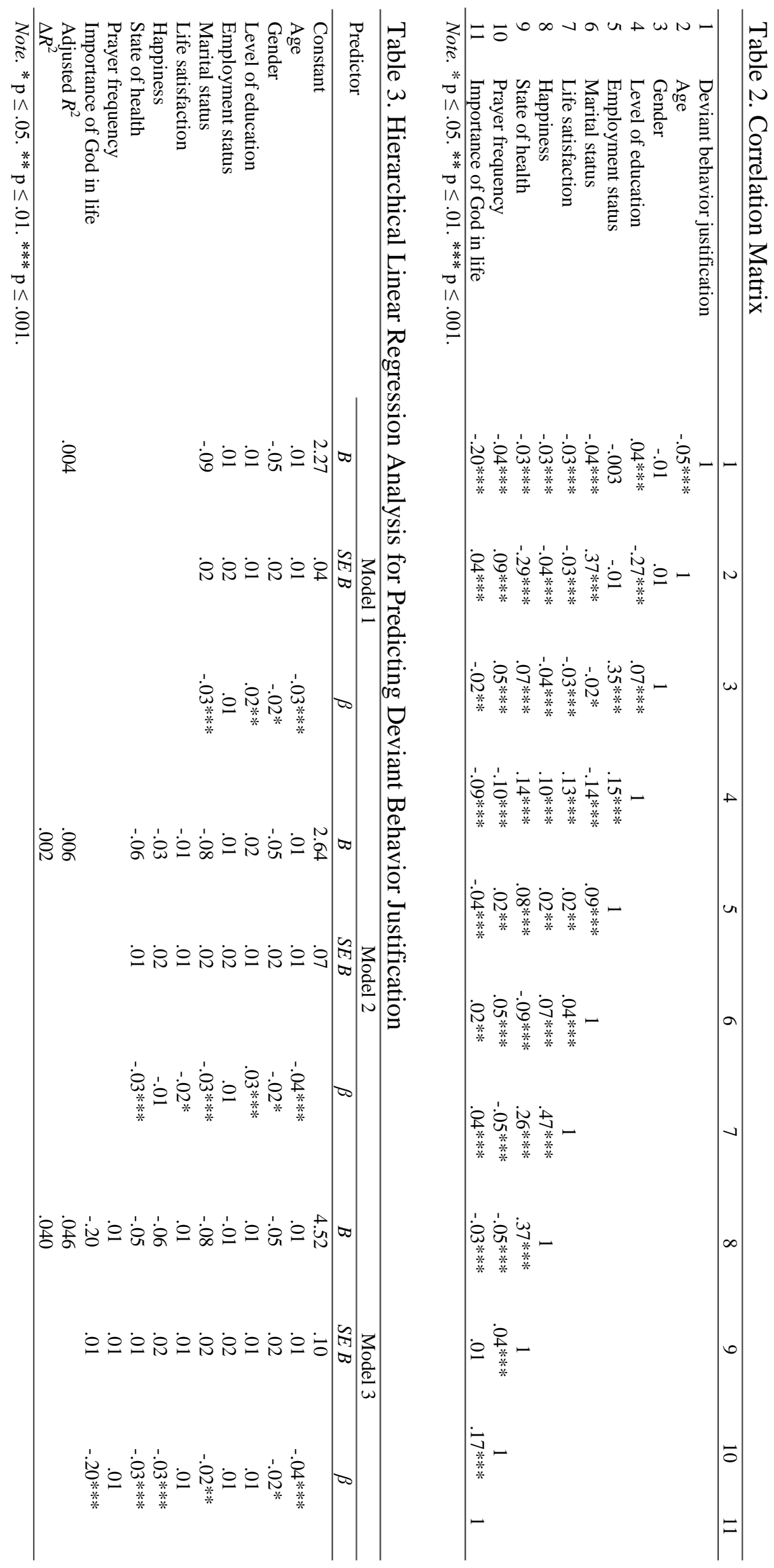


Using hierarchical linear regression, three models predicting deviant behavior justification were tested and presented in Table 3. Model 1 with only sociodemographic variables could only predict $0.4 \%$ of variances in deviant behavior justification with $R^{2}=.004$ $(\mathrm{F}(5,20553)=16.65, \mathrm{p} \leq .001)$. With the addition of subjective well-being variables, Model 2 was slightly better, predicting $0.6 \%$ of variances with $R^{2}=.006(\mathrm{~F}(8,20550)=16.54, \mathrm{p} \leq$ $.001)$. Comparatively, Model 3 was the best model. It predicted the largest variances, specifically $4.6 \%$ of variances in deviant behavior justification with $R^{2}=.046(\mathrm{~F}(10,20548)=$ $100.42, \mathrm{p} \leq .001)$.

Examining the predictors individually, four out of five sociodemographic variables in Model 1 were statistically significant predictors of deviant behavior justification: age $(\beta=.03$, $\mathrm{p} \leq .001)$, gender $(\beta=-.02, \mathrm{p} \leq .05)$, level of education $(\beta=.02, \mathrm{p} \leq .01)$, and marital status $(\beta$ $=.03, \mathrm{p} \leq .001)$. However, the standardized beta coefficients were too low. Similar observation was made in Model 2 with the addition of subjective well-being variables. Two of the three variables were statistically significant predictors: life satisfaction $(\beta=-.02, \mathrm{p} \leq .05)$ and state of health $(\beta=.03, \mathrm{p} \leq .001)$. In Model 3 , religiousness measured in the form of prayer frequency was not a predictor. However, religiousness operationalized as having the worldview of God being important in one's life was a statistically significant predictor. Furthermore, it is a strong predictor. The higher the degree of importance, the more it predicted a decreased in deviant behavior justification $(\beta=.20, \mathrm{p} \leq .001)$.

\section{Discussion}

Three main findings have been observed in this study. Firstly, sociodemographic factors were statistically significant predictors of justifying deviant behavior among Muslims (four out of five variables in Model 1). Secondly, subjective well-being factors were also predictors (two out of three variables in Model 2). However, in both cases, the model's explained variances were too low; the same finding was observed with standardized beta coefficients of predictors. Thirdly, perceived religiousness in the form of having the worldview of God being important in life was not only a statistically significant predictor but also a strong factor; but this was not observed for prayer frequency.

In relation to the first finding, past studies have observed inconsistencies for sociodemographic factors, for example sex differences in deviant behaviors (see Lanctôt et al., 2007; Roxas \& Stoneback, 2004). Putting aside the decreased or increased in the degree of deviant behavior justification in the present finding, these predictors may not have much impact in real life as can be inferred with the explained variances. This also applies to the second finding on subjective well-being. However, the lack of relationship between wellbeing and ethical beliefs have been described as counter-intuitive (Singh, 2018). While the significance of the relationship was observed, the finding may still fall into the counterintuitive category. A clearer picture of the relationship between subjective well-being and deviant behavior could be obtained by mapping the different facets of the former, such as eudaimonic subjective well-being. The differences between ethical judgment, beliefs, attitude, and other manifestations of similar constructs might also hold the key to understanding the justifying of deviant behavior as predicted by subjective well-being.

Additionally, subjective well-being had been studied as being related to or the outcome of ethical leadership (Ahmad et al., 2020), ethical dilemma (Nakar, 2019), personal attitude (James Jr., 2011), and perceived managers' behavioral integrity (Prottas, 2013). However, the causal direction is not strong even though it is intuitive that successful management of ethical issues can produce positive affect such as eudaimonia. Whether the reverse is true or not, it can be tested with a rigorous experimental study that is undoubtedly fraught with methodological and ethical challenges. 
On the third finding on perceived religiousness variables, it was found that having a strong notion of God being important in life was a significant predictor of deviant behavior justification, while prayer frequency was not a predictor. This suggests that to justified, to act on, or to avoid deviant behavior may be linked to how the person views his or her personal relationship with God in life. This finding suggests having such worldview can be far more important than prayer frequency. This can be explained by how religion plays a role cognitively as a regulatory mechanism of an individual (McCullough \& Willoughby, 2009) based on the theory of self-regulation (Carver \& Scheier, 1998). Furthermore, the finding also suggests that a practicing Muslim may only be ritualistically inclined or due to cultural norm, which past studies have observed (Aminnuddin, 2019b, e.g., 2019c). The same individual may not be intrinsically religious or living a life adhering to the theological teaching of Islam, other than the ritual aspect. This needs to be studied further.

In contrast to previous research that noted the benefits of perceived religiousness through prayer frequency, for example as a protective factor of depression (Hodge et al., 2016), this present study found no such evidence toward reducing the deviant behavior justification. This can be due to several reasons. Religiousness itself may differ regionally (Chalfant \& Heller, 1991), and even religious immigrants can be affected by religious native population (Van Tubergen \& Sindradóttir, 2011), with outcomes linked to religion observed to vary depending on the religious history of a country or society (Stam et al., 2013). Furthermore, an individual's personal values or beliefs may change in priority or in acting upon it depending on various situations including in organization, social relation, and facing a crisis (De Wet et al., 2019). It is appropriate to argue that the way religiousness influences a person may vary over "vary over time, person, situation, and culture" (Batson \& Stocks, 2004, p. 153).

Additionally, prayer is associated with psychological outcomes like subjective wellbeing and purpose in life (Francis \& Evans, 1995), lower depression level (Anderson \& Nunnelley, 2016). The effect of intercessory prayer on prosocial behavior had also been demonstrated albeit with complexity in the findings (Greenway, 2020). However, to examine the effect of private prayer on specific behaviors had not been studies well and may require more accurate measures and research design with more controls, rather than merely selfreported.

It is also possible that while past studies measured perceived religiousness through the frequency of prayer and even attendance of religious activities, how people act and think concerning religion have started to change. Perceived religiousness in the form of rituals and practices and other religious behaviors are becoming more of daily occurrences as a routine in an Islamic lifestyle, rather than being in touch with the Divine (Aminnuddin, 2019b, 2019c; Karoui \& Khemakhem, 2019). These behaviors, including prayers, tend to be acted upon due to social expectation and culture. Hence, this can explain why the observed predictive variable in this study is only to have the mindset that God is important in a person's life, rather than a ritualistic form of religiousness.

\section{Implications to Islamic Guidance and Counseling}

Theologically, Islamic creed emphasizes the principle of God-consciousness or Godfearing piety (taqwa) as the differentiation factor of one's rank in the hereafter, more so than characteristics such as ethnicity and lineage. This also includes sex differences. The internalization of this Islamic principle may dilute the effects of sociodemographic characteristics on justifying deviant behavior. In other words, to the extent that this principle is internalized, differences in God-consciousness or God-fearing piety-of which, the importance of God in life is much closer semantically relative to prayer behavior-may be a more effective predictor of deviant behavior. 
As such, findings from this research, particularly on perceived religiousness within the domain of importance of God in life, can be used in professional practice. For example, without dismissing the significance of ritualistic aspect, practitioners of psychotherapy or counseling may want to start by focusing on God being in one's life and emphasizing the importance of this, framing that specific notion as a building block in creating an Islamic worldview. However, concerning this premise, practitioners need to be cautious and aware of what a client wants and willing to do. Hence, the importance of practitioners to integrate Islamic psychological framework or Islamic worldview within their practices is only feasible and ethical if religion is deemed to be important in the lives of the individuals they are interacting with.

\section{Limitations and Suggestions for Further Research}

Several limitations and future recommendations are presented here. Regional differences in perceived religiousness could affect the nature of its relationship to ethical behavior. At the measurement level, differences could be established by examining measurement invariance or differential item functioning. However, such an analysis could not be performed due to the available constructs and limited number of items in the data set. To test the hypothesis that region-based differences in religiousness exist (beyond the descriptive distribution of scores that can be achieved with the existing data set), future study can examine comprehensive measures of prayer or other ritual-based measures of religiousness and importance of God in different regions. Concerning the variables in this study, it is a limitation that constructs for subjective well-being and perceived religiousness are measured using single-item indicators. This may or may not affect the reliability and validity of the assessment, as existing literature are not consistent on single-item versus multiple-item instruments. However, for future research, it is recommended to use more complex instruments, including taking into consideration of constructs being multidimensional. Furthermore, the dynamic surrounding deviant behaviors also need to be examined. For example, situational was found to influence the relationship between faith maturity and ethical sensitivity (Saat et al., 2009). In addition, an argument was made to examine the situational factor for a specific deviant behavior, namely taking a bribe (McGee et al., 2015). A richer and more situationally sensitive measure of deviant behavior justification or deviant behavior itself could be employed in future studies.

\section{CONCLUSIONS}

Other than determining the predictors, this present study provides a novel understanding of the brain-behavior nexus specifically concerning Muslims justifying deviant behavior when two forms of perceived religiousness were being compared: behavioral that is prayer frequency (ritualistic) versus cognitive that is the mindset of God being important in life (worldview). It is the latter that is a major protective predictor as indicated by predicting less justifying of deviant behavior. There is no evidence to support ritualistic form of perceived religiousness as a predictor, although this needs to be further examined. Similarly, sociodemographic factors are not strong predictors; the same goes for subjective well-being. Both are only able to explain minimal variances of the tested models, compared to a model with perceived religiousness. This is important because this implies that religiousness may be a far more important factor than the others. However, this influence may only be found in societies where Islam is culturally important and dominant. Even if this is not observed at the societal level, the effect may be strong in individuals if they have strong internalization of their beliefs. This present study also noted that ritualistic action is not a predictor even though theologically it should be one. This can be of interest for future scholars who are looking into the paradigm of belief-behavior among individuals, whether religion is (1) being internalized 
and externalized, (2) being externalized but not internalized, or (3) being internalized but not externalized by Muslims in the contemporary world.

\section{ACKNOWLEDGMENTS}

The authors would like to thank everyone who was involved from the beginning until the end of the process. This includes our colleagues who gave feedbacks, as well as the editorial team and the reviewers who handled the manuscript and provided valuable insights in improving it further.

\section{AUTHOR CONTRIBUTIONS STATEMENT}

NAA designed, conceptualized, and led the project. NAA cleaned and prepared the data. NAA and HSAH performed the statistical analysis and wrote the results, findings, and discussion. Both NAA and HSAH wrote and edited the manuscript.

\section{REFERENCES}

Abu-Raiya, H. (2013). The psychology of Islam: Current empirically based knowledge, potential challenges, and directions for future research. In K. I. Pargament, J. J. Exline, \& J. W. Jones (Eds.), APA handbook of psychology, religion, and spirituality (Vol 1): Context, theory, and research (pp. 681-695). American Psychological Association. https://doi.org/https://doi.org/10.1037/14045-038

Ahmad, S., Sohal, A. S., \& Cox, J. W. (2020). Leading well is not enough: A new insight from the ethical leadership, workplace bullying and employee well-being relationships. European Business Review, 32(2), 159-180. https://doi.org/10.1108/EBR-08-2018-0149

Aminnuddin, N. A. (2019a). Discriminatory attitude toward vulnerable groups in Singapore: Prevalence, predictors, and pattern. The Journal of Behavioral Science, 14(2), 15-30. https://www.tci-thaijo.org/index.php/IJBS/article/view/167086

Aminnuddin, N. A. (2019b). Predicting Islamic ethical work behavior using the theory of planned behavior and religiosity in Brunei. The Journal of Behavioral Science, 14(1), 1-13. https://www.tci-thaijo.org/index.php/IJBS/article/view/147140

Aminnuddin, N. A. (2019c). Demographic factors and religiosity dimensions as predictors of Islamic ethical work behavior in Brunei. Psychological Thought, 12(2), 185-201. https://doi.org/10.5964/psyct.v12i2.386

Aminnuddin, N. A. (2020a). Ethnic differences and predictors of racial and religious discriminations among Malaysian Malays and Chinese. Cogent Psychology, 7(1), 1766737. https://doi.org/10.1080/23311908.2020.1766737

Aminnuddin, N. A. (2020b). Perceiving university education as more important for men than for women: Gender differences and predictors of this perception in Muslim societies. Psychological Thought, 13(1), 99-126. https://doi.org/10.37708/psyct.v13i1.392

Aminnuddin, N. A. (2020c). Dataset on Islamic ethical work behavior among Bruneian Malay Muslim teachers with measures concerning religiosity and theory of planned behavior. Data in Brief, 29, 105157. https://doi.org/10.1016/j.dib.2020.105157

Anderson, J. W., \& Nunnelley, P. A. (2016). Private prayer associations with depression, anxiety and other health conditions: An analytical review of clinical studies. Postgraduate Medicine, 128(7), 635-641. https://doi.org/10.1080/00325481.2016.1209962

Appelbaum, S. H., Iaconi, G. D., \& Matousek, A. (2007). Positive and negative deviant workplace behaviors: Causes, impacts, and solutions. Corporate Governance, 7(5), 586-598. https://doi.org/10.1108/14720700710827176

Baker, T., Ray, J. V., \& Zgoba, K. (2020). Race differences in the effects of early school behavior problems and substance use type on lifetime arrest. Deviant Behavior, 1-12. 
https://doi.org/10.1080/01639625.2020.1815252

Bakken, N. W. (2021). Risk factors and correlates of self-injurious behavior and suicidal ideation among college students. Deviant Behavior, 42(1), 68-79. https://doi.org/10.1080/01639625.2019.1651447

Balish, S. M., Conacher, D., \& Dithurbide, L. (2016). Sport and recreation are associated with happiness across countries. Research Quarterly for Exercise and Sport, 87(4), 382-388. https://doi.org/10.1080/02701367.2016.1229863

Batson, C. D., \& Stocks, E. L. (2004). Religion: Its core psychological functions. In J. Greenberg, S. L. Koole, \& T. Pyszczynski (Eds.), Handbook of Experimental Existential Psychology (pp. 141-155). Guilford Press. Google Scholar

Beja, E. L. (2018). The U-shaped relationship between happiness and age: Evidence using world values survey data. Quality \& Quantity, 52, 1817-1829. https://doi.org/10.1007/s11135-017-0570-z

Boddy, C. R. (2014). Corporate Psychopaths, conflict, employee affective well-being and counterproductive work behaviour. Journal of Business Ethics, 121(1), 107-121. https://doi.org/10.1007/s10551-013-1688-0

Bruni, L., \& Stanca, L. (2006). Income aspirations, television and happiness: Evidence from the World Values Survey. Kyklos, 59(2), 209-225. https://doi.org/10.1111/j.14676435.2006.00325.x

Carver, C. S., \& Scheier, M. F. (1998). On the self-regulation of behavior. Cambridge University Press. https://doi.org/10.1017/CBO9781139174794

Chalfant, H. P., \& Heller, P. L. (1991). Rural/urban versus regional differences in religiosity. Review of Religious Research, 33(1), 76-86. https://doi.org/10.2307/3511262

De Wet, J., Wetzelhütter, D., \& Bacher, J. (2019). Revisiting the trans-situationality of values in Schwartz's Portrait Values Questionnaire. Quality \& Quantity, 53(2), 685-711. https://doi.org/10.1007/s11135-018-0784-8

Desmond, S. A., Ulmer, J. T., \& Bader, C. D. (2013). Religion, self control, and substance use. Deviant Behavior, 34(5), 384-406. https://doi.org/10.1080/01639625.2012.726170

Dubois, D., Rucker, D. D., \& Galinsky, A. D. (2015). Social class, power, and selfishness: When and why upper and lower class individuals behave unethically. Journal of Personality and Social Psychology, 108(3), 436-449. https://doi.org/10.1037/pspi0000008

Easterlin, R. A., McVey, L. A., Switek, M., Sawangfa, O., \& Zweig, J. S. (2010). The happiness-income paradox revisited. Proceedings of the National Academy of Sciences, 107(52), 22463-22468. https://doi.org/10.1073/pnas.1015962107

Eichhorn, J. (2012). Happiness for believers? Contextualizing the effects of religiosity on lifesatisfaction. European Sociological Review, 28(5), 583-593. https://doi.org/10.1093/esr/jcr027

Francis, L. J., \& Evans, T. E. (1995). The psychology of christian prayer: A review of empirical research. Religion, 25(4), 371-388. https://doi.org/10.1016/S0048$721 \mathrm{X}(05) 80021-1$

$\mathrm{Fu}, \mathrm{W}$. (2014). The impact of emotional intelligence, organizational commitment, and job satisfaction on ethical behavior of Chinese employees. Journal of Business Ethics, 122(1), 137-144. https://doi.org/10.1007/s10551-013-1763-6

Giacalone, R. A., \& Promislo, M. D. (2010). Unethical and unwell: Decrements in well-being and unethical activity at work. Journal of Business Ethics, 91(2), 275-297. https://doi.org/10.1007/s10551-009-0083-3

Gino, F., \& Pierce, L. (2009). The abundance effect: Unethical behavior in the presence of wealth. Organizational Behavior and Human Decision Processes, 109(2), 142-155. https://doi.org/10.1016/j.obhdp.2009.03.003 
Goode, E. (2019). Deviant Behavior. Routledge. https://doi.org/10.4324/9780429202902

Greenway, T. S. (2020). A review of theories accounting for the relationship between intercessory prayer and prosocial behavior: Current research and future directions. Psychology of Religion and Spirituality, 12(1), 66-76. https://doi.org/10.1037/rel0000209

Hodge, D. R., Zidan, T., \& Husain, A. (2016). Depression among Muslims in the United States: Examining the role of discrimination and spirituality as risk and protective factors. Social Work, 61(1), 45-52. https://doi.org/10.1093/sw/swv055

Hong Chui, W., Khiatani, P. V., \& Kiconco, M. (2020). An examination of the differential impacts of social bonds and organized crime affiliation on male and female youth street gang members' delinquency. Deviant Behavior, 1-21. https://doi.org/10.1080/01639625.2020.1787761

Husin, W. N. W., \& Kernain, N. F. Z. (2020). The influence of individual behaviour and organizational commitment towards the enhancement of Islamic work ethics at Royal Malaysian Air Force. Journal of Business Ethics, 166(3), 523-533. https://doi.org/10.1007/s10551-019-04118-7

Inglehart, R., Haerpfer, C., Moreno, A., Welzel, C., Kizilova, K., Diez-Medrano, J., Lagos, M., Norris, P., Ponarin, E., \& Puranen, B. (Eds.). (2014). World Values Survey: Round six - country-pooled datafile version: http://www.worldvaluessurvey.org/WVSDocumentationWV6.jsp.

Isa, A. (2021). Engendering domestic harmony. Journal of Islamic Governance, 11. https://doi.org/10.53105/tp11

James Jr., H. S. (2011). Is the just man a happy man? An empirical study of the relationship between ethics and subjective well-being. KYKLOS, 64(2), 193-212. https://doi.org/10.1111/j.1467-6435.2011.00502.x

Kadafi, A., Alfaiz, A., Ramli, M., Asri, D. N., \& Finayanti, J. (2021). The impact of Islamic counseling intervention towards students' mindfulness and anxiety during the COVID19 pandemic. Islamic Guidance and Counseling Journal, 4(1), 55-66. https://doi.org/10.25217/igcj.v4i1.1018

Karoui, S., \& Khemakhem, R. (2019). Factors affecting the Islamic purchasing behavior - A qualitative study. Journal of Islamic Marketing. https://doi.org/10.1108/JIMA-12-20170145

Keller, A. C., Smith, K. T., \& Smith, L. M. (2007). Do gender, educational level, religiosity, and work experience affect the ethical decision-making of U.S. accountants? Critical Perspectives on Accounting, 18(3), 299-314. https://doi.org/10.1016/j.cpa.2006.01.006

Lanctôt, N., Cernkovich, S. A., \& Giordano, P. C. (2007). Delinquent behavior, official delinquency, and gender: Consequences for adulthood functioning and well-being. Criminology, 45(1), 131-157. https://doi.org/10.1111/j.1745-9125.2007.00074.x

McCaghy, C., Capron, T., Jamieson, J. D., \& Carey, S. H. (2016). Deviant Behavior. Routledge. https://doi.org/10.4324/9781315664323

McCullough, M. E., \& Willoughby, B. L. B. (2009). Religion, self-regulation, and selfcontrol: Associations, explanations, and implications. Psychological Bulletin, 135(1), 69-93. https://doi.org/10.1037/a0014213

McGee, R. W., Benk, S., \& Yüzbaş1, B. (2015). Religion and ethical attitudes toward accepting a bribe: A comparative study. Religions, 6(4), 1168-1181. https://doi.org/10.3390/rel6041168

Muarifah, A., Muyana, S., \& Hidayah, H. N. (2020). The effect of religiosity on poor adult woman's meaningfulness of life. Islamic Guidance and Counseling Journal, 3(2), 9399. https://doi.org/10.25217/igcj.v3i2.569

Muhamad, N., Khamarudin, M., \& Fauzi, W. I. M. (2019). The role of religious motivation in 
an international consumer boycott. British Food Journal, 121(1), 199-217. https://doi.org/10.1108/BFJ-02-2018-0118

Muhamad, N., \& Mizerski, D. (2010). The constructs mediating religions' influence on buyers and consumers. Journal of Islamic Marketing, 1(2), 124-135. https://doi.org/10.1108/17590831011055860

Nakar, S. (2019). Impact of ethical dilemmas on well-being of teachers in vocational education and training in Queensland, Australia. International Journal of Training Research, 17(1), 35-49. https://doi.org/10.1080/14480220.2019.1602122

Nie, F. (2020). Adolescent porn viewing and religious context: Is the eye still the light of the body? Deviant Behavior, 1-14. https://doi.org/10.1080/01639625.2020.1747154

Pearce, L. D., Uecker, J. E., \& Denton, M. L. (2019). Religion and adolescent outcomes: How and under what conditions religion matters. Annual Review of Sociology, 45, 201-222. https://doi.org/10.1146/annurev-soc-073117-041317

Piff, P. K., Stancato, D. M., Cote, S., Mendoza-Denton, R., \& Keltner, D. (2012). Higher social class predicts increased unethical behavior. Proceedings of the National Academy of Sciences, 109(11), 4086-4091. https://doi.org/10.1073/pnas.1118373109

Piff, P. K., Stancato, D. M., \& Horberg, E. J. (2016). Wealth and wrongdoing: Social class differences in ethical reasoning and behavior. In J.-W. van Prooijen \& P. A. M. van Lange (Eds.), Cheating, corruption, and concealment: The roots of dishonesty (pp. 185207). Cambridge University Press. Google Scholar

Prottas, D. J. (2013). Relationships among employee perception of their manager's behavioral integrity, moral distress, and employee attitudes and well-being. Journal of Business Ethics, 113, 51-60. https://doi.org/10.1007/s10551-012-1280-z

Reisel, W., Probst, T., Chia, S. L., Maloles, C., \& König, C. (2010). The effects of job insecurity on job satisfaction, organizational citizenship behavior, deviant behavior, and negative emotions of employees. International Studies of Management and Organization, 40(1), 74-91. https://doi.org/10.2753/IMO0020-8825400105

Rice, G. (1999). Islamic ethics and the implications for business. Journal of Business Ethics, 18(4), 345-358. https://doi.org/10.1023/A:1005711414306

Rifani, E., Sugiyo, S., \& Purwanto, E. (2021). The mediation effect of moral disengagement on spiritual-religious attitudes and academic dishonesty among guidance and counseling students. Islamic Guidance and Counseling Journal, 4(1), 33-42. https://doi.org/10.25217/igcj.v4i1.1147

Robinson, S. L., Wang, W., \& Kiewitz, C. (2014). Coworker behaving badly: The impact of coworker deviant behavior upon individual employees. Annual Review of Organizational Psychology and Organizational Behavior, 1, 123-143. https://doi.org/10.1146/annurev-orgpsych-031413-091225

Roxas, M. L., \& Stoneback, J. Y. (2004). The importance of gender across cultures in ethical decision-making. Journal of Business Ethics, 50(2), 149-165. https://doi.org/10.1023/B:BUSI.0000022127.51047.ef

Saat, M. M., Porter, S., \& Woodbine, G. (2009). Does religiosity influence ethical sensitivity? An investigation on Malaysian future accountants. Malaysian Accounting Review, 8(2), 17-41. http://dx.doi.org/10.24191/mar.v8i2.254

Salam, M. T., Muhamad, N., \& Leong, V. S. (2019). Muslim millennials' attitudes towards fashion advertising. International Journal of Advertising, 38(5), 796-819. https://doi.org/10.1080/02650487.2019.1585648

Selim, S. (2008). Life satisfaction and happiness in Turkey. Social Indicators Research, 88(3), 531-562. https://doi.org/10.1007/s11205-007-9218-z

Simons, L. G., Burt, C. H., \& Peterson, F. R. (2009). The effect of religion on risky sexual behavior among college students. Deviant Behavior, 30(5), 467-485. 
https://doi.org/10.1080/01639620802296279

Singh, R. (2018). Money, religiosity, and spiritual well-being: Does it impact consumers' ethical beliefs? Evidence from India. DECISION, 45(3), 259-269. https://doi.org/10.1007/s40622-018-0190-z

Smith, T. R., Rizzo, E., \& Empie, K. M. (2005). Yielding to deviant temptation: A quasiexperimental examination of the inhibiting power of intrinsic religious motivation. Deviant Behavior, 26(5), 463-481. https://doi.org/10.1080/016396290968416

Stam, K., Verbakel, E., \& De Graaf, P. M. (2013). Explaining variation in work ethic in Europe. European $\quad$ Societies, $15(2), \quad 268-289$. https://doi.org/10.1080/14616696.2012.726734

Trautmann, S. T., van de Kuilen, G., \& Zeckhauser, R. J. (2013). Social class and (un)ethical behavior: A framework, with evidence from a large population sample. Perspectives on Psychological Science, 8(5), 487-497. https://doi.org/10.1177/1745691613491272

Van Tubergen, F., \& Sindradóttir, J. Í. (2011). The religiosity of immigrants in Europe: A cross-national study. Journal for the Scientific Study of Religion, 50(2), 272-288. https://doi.org/10.1111/j.1468-5906.2011.01567.x

Walker, A. G., Smither, J. W., \& DeBode, J. (2012). The effects of religiosity on ethical judgments. Journal of Business Ethics, 106(4), 437-452. https://doi.org/10.1007/s10551-011-1009-4

Wang, X., \& Jang, S. J. (2017). The relationship between religion and deviance in a largely rrreligious country: Findings from the 2010 China General Social Survey. Deviant Behavior, 38(10), 1120-1140. https://doi.org/10.1080/01639625.2016.1241059

Westman, M., \& Etzion, D. (2001). The impact of vacation and job stress on burnout and absenteeism. Psychology and Health, 16(5), 595-606. https://doi.org/10.1080/08870440108405529

Wu, R., Ming, S., \& Huang, F. (2019). Guanxi and unethical behavior in the Chinese workplace: Job satisfaction as a mediator. Social Behavior and Personality: An International Journal, 47(3), 1-14. https://doi.org/10.2224/sbp.7294

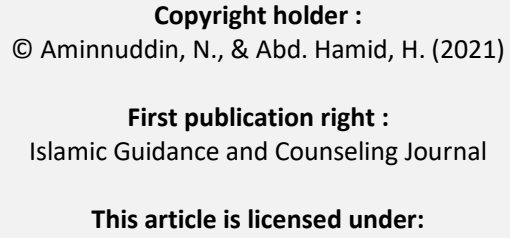

